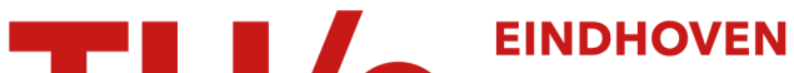 UNIVERSITY OF TECHNOLOGY
}

\section{Bimodal ultrahigh molecular weight polyethylenes produced from supported catalysts}

\section{Citation for published version (APA):}

Liu, H., Bastiaansen, C. W. M., Goossens, J. G. P., Schenning, A. P. H. J., \& Severn, J. R. (2017). Bimodal ultrahigh molecular weight polyethylenes produced from supported catalysts: the challenge of using a combined catalyst system. Macromolecular Chemistry and Physics, 218(5), [1600490].

https://doi.org/10.1002/macp.201600490

\section{Document license:}

TAVERNE

DOI:

10.1002/macp.201600490

Document status and date:

Published: 01/03/2017

\section{Document Version:}

Publisher's PDF, also known as Version of Record (includes final page, issue and volume numbers)

\section{Please check the document version of this publication:}

- A submitted manuscript is the version of the article upon submission and before peer-review. There can be important differences between the submitted version and the official published version of record. People interested in the research are advised to contact the author for the final version of the publication, or visit the $\mathrm{DOI}$ to the publisher's website.

- The final author version and the galley proof are versions of the publication after peer review.

- The final published version features the final layout of the paper including the volume, issue and page numbers.

Link to publication

\section{General rights}

Copyright and moral rights for the publications made accessible in the public portal are retained by the authors and/or other copyright owners and it is a condition of accessing publications that users recognise and abide by the legal requirements associated with these rights.

- Users may download and print one copy of any publication from the public portal for the purpose of private study or research.

- You may not further distribute the material or use it for any profit-making activity or commercial gain

- You may freely distribute the URL identifying the publication in the public portal.

If the publication is distributed under the terms of Article $25 \mathrm{fa}$ of the Dutch Copyright Act, indicated by the "Taverne" license above, please follow below link for the End User Agreement:

www.tue.nl/taverne

Take down policy

If you believe that this document breaches copyright please contact us at:

openaccess@tue.nl

providing details and we will investigate your claim. 


\title{
Bimodal Ultrahigh Molecular Weight Polyethylenes Produced from Supported Catalysts: The Challenge of Using a Combined Catalyst System
}

\author{
Hao Liu, Cees W. M. Bastiaansen, Johannes G. P. Goossens, \\ Albertus P. H. J. Schenning, John R. Severn*
}

Molecular precatalysts complexes $(n \mathrm{BuCp}){ }_{2} \mathrm{ZrCl}_{2}(\mathrm{Zr})$ and $\left(\eta 1: \eta 5-\mathrm{Me}_{2} \mathrm{NCH}_{2} \mathrm{CH}_{2} \mathrm{C}_{5} \mathrm{Me}_{4}\right) \mathrm{CrCl}_{2}(\mathrm{Cr})$ have been successfully supported on silica nanoparticles, via a single support (SS) or a double support (DS) strategy. These catalyst systems have been successfully used to produce bimodal polyethylenes with an ultrahigh molecular weight polyethylene content in a single reactor. The SS and DS catalyst systems have been fully evaluated under an identical polymerization condition to assess the challenges in tailoring the molecular weight distribution. The results show that a detrimental interaction exists between $\mathrm{Zr}$ and $\mathrm{Cr}$ catalysts, part of the $\mathrm{Cr}$ catalyst species is deactivated during polymerization in the both DS and SS systems. The detrimental interaction in the DS system is reduced because the catalysts are supported on separate nanoparticles. But, surprisingly the two catalysts in the DS system are still able to "communicate" to each other via cocatalyst-induced catalyst leaching or other potential reasons.

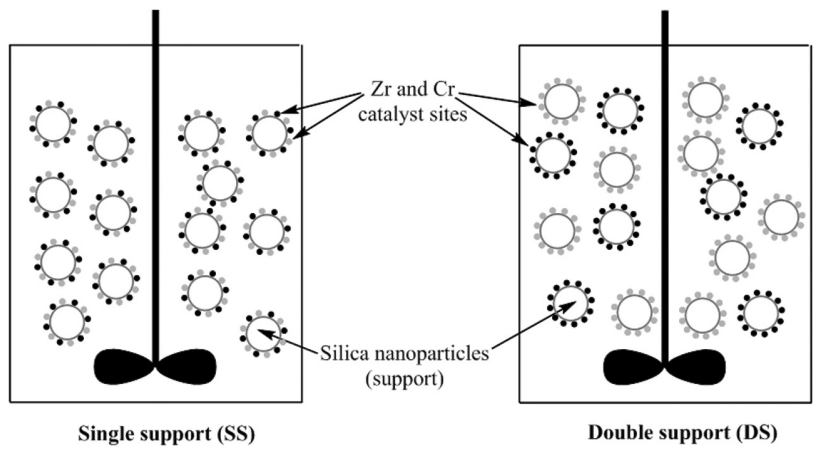

H. Liu, Dr. C. W. M. Bastiaansen, Prof. A. P. H. J. Schenning, Dr. J. R. Severn

Functional Organic Materials \& Devices

Department of Chemical Engineering and Chemistry

Eindhoven University of Technology

$5600 \mathrm{MB}$, Eindhoven, The Netherlands

E-mail: j.severn@tue.nl

Dr. C. W. M. Bastiaansen

School of Engineering and Materials Science

Queen Mary

University of London

London E1 4NS, UK

Dr. J. G. P. Goossens

Laboratory of Polymer Materials

Department of Chemical Engineering and Chemistry

Eindhoven University of Technology

$5600 \mathrm{MB}$, Eindhoven, The Netherlands

Dr. J. R. Severn

DSM Ahead B.V., NL-616oMD, Geleen, The Netherlands

\section{Introduction}

Ultrahigh molecular weight polyethylene (UHMwPE) is a linear (or few short branches) polyethylene with a molecular weight (MW) higher than million $\mathrm{g} / \mathrm{mol}$. This material has extraordinary mechanical properties in terms of tensile strength ${ }^{[1]}$ toughness, ${ }^{[2]}$ and wear. ${ }^{[3]}$ Due to the very high melt viscosity, UHMwPE is normally processed by compression molding or ram extrusion. Nevertheless, fusion defects in the melt-processed UHMwPE strongly affect the service life of the material. ${ }^{[4]}$ In previous studies, it was found that during processing, the short chain part of the molecular weight distribution (MWD) plays a key role in eliminating the fusion defects of the consolidated material. ${ }^{[5,6]}$ Therefore, a bimodal distribution with an increased short chain tail could be a route toward improving the melt processing and properties of UHMwPE. In addition, small 
particle sized of the polymer powder may also improve the consolidation of UHMwPE and thus reduce fusion defects in the final products.

Commercially available bimodal PEs have a comparatively low weight-average molecular weight $\left(<200 \mathrm{~kg} \mathrm{~mol}^{-1}\right)$ and are typically produced in a cascade reactor by multisite Ziegler-Natta catalysts. ${ }^{[7-10]}$ In recent decades, molecular catalysts have aroused a lot of interest due to the capability to produce polymers with narrow molecular weight distributions and a comparatively uniform comonomer incorporation across the MWD. ${ }^{[1]}$ A variety of studies were performed to generate a bimodal or a broad molecular weight distribution polyethylene in a single reactor by using molecular precatalysts. ${ }^{[12-38]}$ In this process, the catalyst systems used are a single molecular precatalyst activated by two different cocatalysts, ${ }^{[18]}$ a molecular precatalyst/ZieglerNatta (or other) hybrid catalyst ${ }^{[13]}$ or, more commonly, by combining two (or more) molecular precatalysts systems. ${ }^{[19-38]}$ The combined molecular catalyst systems are either run in homogeneous or particle forming processes, however, for the former running UHMwPE in solution is not an option, due to the high viscosity issues in working up the reactor solution, especially devolatization and downstream processing. For the single support system two or more precatalysts, selected for their molecular weight capabilities and response to comonomer or hydrogen are coimmobilized on a single support particle (Figure 1a). These catalyst systems are able to produce multimodal MWD ethylene homopolymers and copolymers under a set polymerization condition. Combined molecular catalysts system in a single reactor is often seen as a cheaper/easier route than traditional cascaded processes for multimodal polymers. This, however, is an

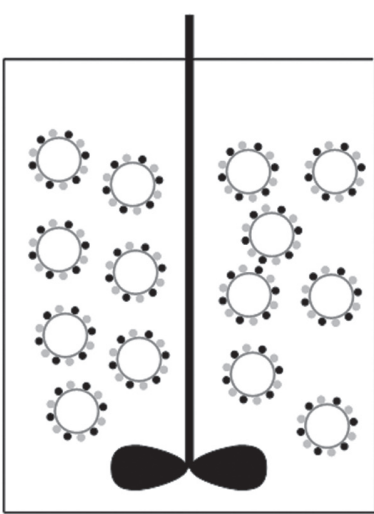

Single support

(a)

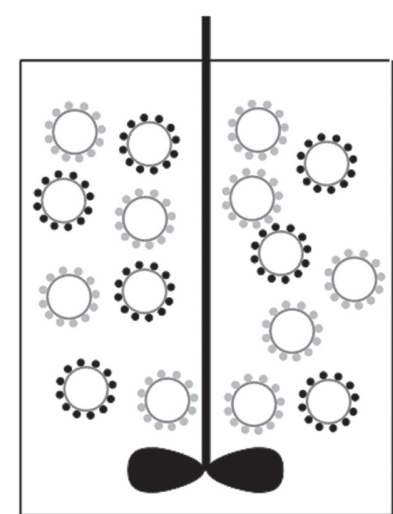

Double support

(b)
Figure 1. a) Silica nanoparticles (NS) with both catalyst species supported and b) mixing silica nanoparticle with two catalyst species separately supported. over-simplistic view and belies the tremendous skill and ingenuity that is needed to translate these sophisticated systems from laboratory batch reactors to large scale continuous industrial processes. The main reason for this challenge comes via virtue of why one selects the individual precatalysts, and that is different reactivity ratios and responses to process variables (pressure, feed ratios, temperature) making process control demanding. However, this difference in reactivity ratios also extends to catalyst/cocatalyst ratios and poisons and also stability in terms of storage/shipment of the catalyst. ${ }^{[39]}$ In addition, one complex may produce hydrogen, yet have a low response to it, whilst the other component is extremely responsive making prediction based on only one component being present difficult. ${ }^{[40]}$ The resulting discrepancies in the kinetics of the catalysts could also cause difficulties in getting a precise control over bimodality. In these cases bimodality is controlled via trimming with one or more of the molecular catalyst components or selective poisoning.

Depending on the nature of the selected catalysts, an interaction between the catalysts can exist in the combined catalyst systems which results in synergistic ${ }^{[41-43]}$ or antagonistic effects. ${ }^{[4]}$ The interaction of catalysts also causes difficulties in controlling/tailoring the bimodality of the products. Therefore, the compatibility of the catalysts needs to be often considered.

For supported catalysts, the catalyst particles can be considered as microreactors. Ideally, one catalyst particle forms one polymer particle and is not impacted by other catalyst particles during the polymerization reaction. Thus, we propose to synthesize bimodal molecular weight distribution PEs using a double support (DS) system (Figure $1 \mathrm{~b}$ ) where the two single-site precatalysts are separately immobilized on silica nanoparticles, for comparison to the single support (SS) system. In principle, the kinetics of the DS particles should not deviate from the individual catalyst components since the catalysts are located on different silica nanoparticles. Using this catalyst support strategy, the interaction between catalysts might be avoidable and thus approach a process where the MW and MWDs can be tailored under identical polymerization conditions. In addition, we expect that the small polymer particles produced by the silica nanoparticle supported catalysts could be able to afford a better degree of mixing for LMW and HMW components than micrometer-sized systems, which is part of a wider investigation inspired by the study of Mülhaupt and co-workers. ${ }^{[15,45,46]}$

In this work, the production of bimodal PEs use single SS and DS catalyst systems were fully studied and were compared. The present goal was to investigate the challenges in producing tailored bimodal polymer in a single reactor with high UHMwPE content. 


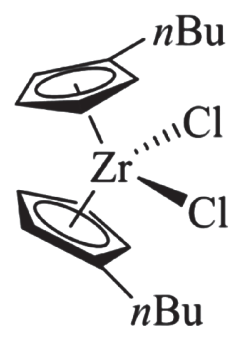

$\mathrm{Zr}$

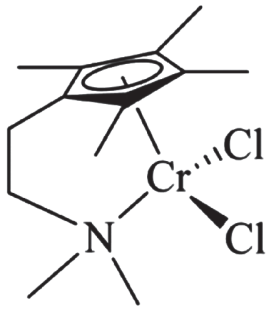

Cr
Scheme 1. Chemical structures of precatalysts.

\section{Experimental Section}

\subsection{Materials}

All of the experiments with air- and/or moisture-sensitive materials were carried out under an inert atmosphere in a glovebox or using standard Schlenk techniques. Methyl cyclohexane $(\mathrm{MCH})$ and toluene were passed over a column containing $\mathrm{Al}_{2} \mathrm{O}_{3}$ and stored over $4 \AA$ molecular sieves. Solvents were degassed by argon bubbling for at least $4 \mathrm{~h}$ prior to use. ( $\eta 1: \eta 5$ $\left.\mathrm{Me}_{2} \mathrm{NCH}_{2} \mathrm{CH}_{2} \mathrm{C}_{5} \mathrm{Me}_{4}\right) \mathrm{CrCl}_{2}$ (Cr, Scheme 1) was kindly donated by SABIC Euro Petrochemicals and $(n B u C p){ }_{2} \mathrm{ZrCl}_{2}$ (Zr, Scheme 1) was purchased from MCAT GmbH. Methylaluminoxane (MAO, 10 wt\% solution in toluene) and triisobutylaluminum $\left(\mathrm{BBu}_{3} \mathrm{Al}\right.$, $1 \mathrm{~m}$ in hexane) were purchased from Sigma-Aldrich and used as a cocatalyst and to scavenge impurities. The $7 \mathrm{~nm}$ fumed nanosilica (NS) was purchased from Sigma-Aldrich and probed by transmission electron microscopy (Figure S1, Supporting Information). Before use, the silica was calcined at $600{ }^{\circ} \mathrm{C}$ for $4 \mathrm{~h}$ under a nitrogen stream. Ethylene (purity 4.5, Linde) and ultrahigh purity nitrogen (Linde) were further purified by passing through columns packed with BTS catalyst (Sigma-Aldrich, copper catalyst for oxygen removal; BASF R3-15) and molecular sieves, respectively.

\subsection{Catalysts Immobilization}

The catalysts were immobilized via a two-step process. The detailed procedure is as follows: Methylaluminoxane (20 mL, $10 \mathrm{wt} \%$ in toluene) was diluted with toluene $(20 \mathrm{~mL}$ ) and added to calcined nanosilica $(2.0 \mathrm{~g})$ under manual agitation. Subsequently, the slurry was heated to $80^{\circ} \mathrm{C}$ and occasionally agitated. After $4 \mathrm{~h}$ the MAO modified nanosilica (MAO/NS) was filtered inside a glove box and washed with $\mathrm{MCH}$ three times to eliminate the residual MAO. The MAO/NS was dried under vacuum for $4 \mathrm{~h}$ to obtain a free-flowing powder. The prepared MAO/NS contained $17.43 \mathrm{wt} \%\left(6.46 \mathrm{mmol} \mathrm{g}^{-1}\right)$ of $\mathrm{Al}$, which was determined by an inductively coupled plasma-atomic emission method, by Kolbe Mikroanalytisches Laboratorium, Mulheiman der Ruhr, Germany.

In the second step, the precatalyst was reacted with $\mathrm{MAO} /$ NS to yield the final silica-supported catalyst system. A typical procedure was as follows: $50 \mathrm{mg} \mathrm{MAO} / \mathrm{NS}$ was first reacted with $1 \mathrm{~mL} \mathrm{Zr}$ (or $\mathrm{Cr}$ ) solution $\left(1 \times 10^{-3} \mathrm{M}\right.$ in toluene) in a sealed vial with a magnetic stirring at $50{ }^{\circ} \mathrm{C}$ (room temperature for $\mathrm{Cr}$ ). After $1 \mathrm{~h}$, the supported catalysts suspension was diluted with $\mathrm{MCH}$ to $10 \mathrm{~mL}$ and was used for polymerization immediately.

In the single support (SS) system, the $50 \mathrm{mg} \mathrm{MAO/NS}$ was sequentially reacted with both $1 \mathrm{~mL} \mathrm{Zr}$ solution $\left(0.2 \times 10^{-3}\right.$ to $0.9 \times 10^{-3} \mathrm{M}$ in toluene) and $1 \mathrm{~mL} \mathrm{Cr}$ solution (0.1 to $0.8 \mu \mathrm{mol}$ in toluene) in the order $\mathrm{Zr}$ prior to $\mathrm{Cr}$.

To confirm that the precatalyst are fully immobilized on silica, the immobilization solution was measured on a Shimadzu UV-3102 PC spectrophotometer with a quartz cuvette equipped with an airtight cap (Figure S2, Supporting Information).

\subsection{Polymerization Reactions}

All of the ethylene polymerization experiments were performed in a $200 \mathrm{~mL}$ steel Büchi autoclave. The polymerization was carried out at $50{ }^{\circ} \mathrm{C}$ and 10 bar monomer pressure. The autoclave was heated in an oven overnight at $160{ }^{\circ} \mathrm{C}$ before each run. After evacuation and purging with argon three times, the $\mathrm{MCH}$ $(80 \mathrm{~mL})$ was charged in the preheated autoclave. Then triisobutylaluminium $\left(\mathrm{iBu}_{3} \mathrm{Al}\right)(0.5 \mathrm{mmol}$ in $10 \mathrm{~mL} \mathrm{MCH})$ was injected as cocatalyst, and the solvent was saturated with ethylene by pressurizing to 10 bar. After 20 min of stirring to allow the cocatalyst to scavenge the reactor, the autoclave was temporarily vented to purge the partial the reactor of argon and to allow the injection of the catalyst slurry. The autoclave was then repressurized to $10 \mathrm{bar}$, and the pressure was maintained throughout the run. The temperature of the autoclave was controlled via a thermostat bath. After $60 \mathrm{~min}$, the system was depressurized, and a mixture of ethanol and diluted hydrochloric acid was injected. The polymer was separated by filtration and dried overnight at $60^{\circ} \mathrm{C}$ under vacuum.

\subsection{Polymer Characterization}

High temperature size exclusion chromatography (HT-SEC) of the PEs was performed at $160{ }^{\circ} \mathrm{C}$ using a Polymer Laboratories PLXT-20 Rapid SEC polymer analysis system (refractive index detector and viscosity detector) with 3 PLgel Olexis $(300 \times 7.5 \mathrm{~mm}$, Polymer Laboratories) columns in series. 1,2,4-Trichlorobenzene was used as eluent at a flow rate of $1 \mathrm{~mL} \mathrm{~min} \mathrm{~m}^{-1}$. The molecular weights were calculated with respect to polyethylene standards (Polymer Laboratories). A Polymer Laboratories PL XT-220 robotic sample handling system was used as autosampler. Polymer samples with 0.5 wt\% antioxidant (Irganox 1010) were dissolved in $\mathrm{TCB}$ at $160^{\circ} \mathrm{C}$ for $3 \mathrm{~h}$ prior to the analysis.

\section{Results and Discussion}

As these experiments were conducted under fed-batch conditions a series of catalyst loading experiments were conducted to investigate the poison limit of the reactor set-up and maximum catalyst loading to avoid loss of internal temperature control which would strongly influence the performance of the catalysts and the molecular weight distribution of polymer products formed. The results showed 


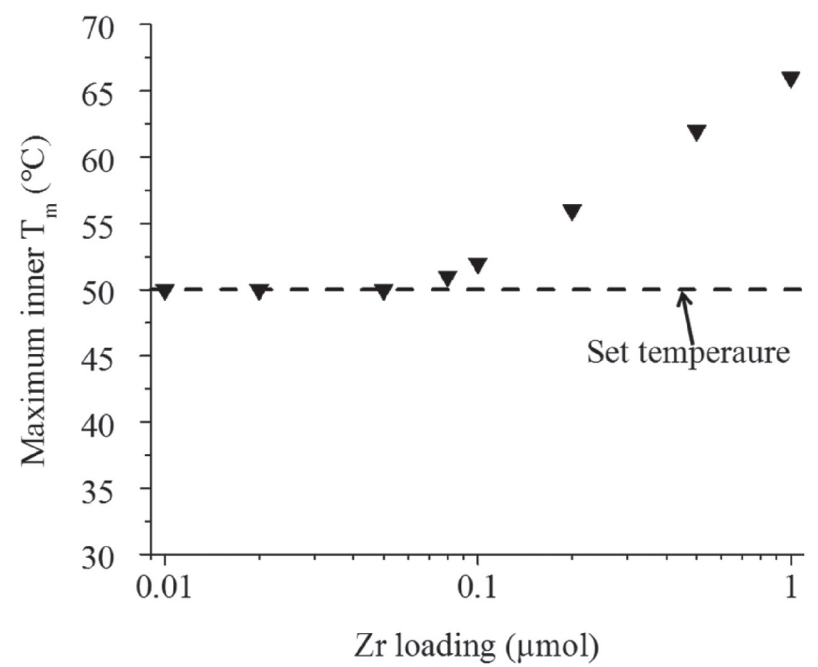

Figure 2. Influence of $\mathrm{Zr}$ concentrate on internal reactor temperature. Conditions: $\mathrm{Al} /$ Cat. $=325$, ethylene pressure $=10 \mathrm{bar}$, temperature $=50{ }^{\circ} \mathrm{C}$, time $=1 \mathrm{~h}$, cocatalyst $0.5 \mathrm{mmol} i \mathrm{Bu}_{3} \mathrm{Al}$, solvent: methyl cyclohexane $100 \mathrm{~mL}$.

that the loss of thermal control starts when a $\mathrm{Zr}$ loading of more than $0.1 \mu \mathrm{mol} \mathrm{Zr}$ catalyst is used in the polymerization system (Figure 2). A further increase in precatalyst loading resulted in a further increase of the internal temperature. The results indicate that a low overall precatalyst concentration is essential to maintain a constant temperature for both DS and SS catalyst systems.

It is well known that impurities ${ }^{[12,47,48]}$ and the $\mathrm{Al} /$ metal ratio ${ }^{[49]}$ can also strongly influence the catalyst performance. The differences of each catalyst's sensitivity to these criteria should be taken into account when using a combined catalysts system to tailor the MW and MWDs. Therefore, the $\mathrm{Al} /$ Catalyst ratios were varied via varying moles of precatalyst ( $\mathrm{Zr}$ or $\mathrm{Cr}$ ) immobilized on $5 \mathrm{mg}$ equivalents MAO/NS. In addition, polymerizations carried out using these catalysts to provide a reference line for the polymers (yield and properties) for truly isolated catalyst under these loading conditions.
The results of ethylene polymerizations carried out with different $\mathrm{Al} /$ catalyst ratios are given in Tables 1 and 2. A very low polymer yield (Entry 1 in both tables) is observed when loading with $0.01 \mu \mathrm{mol}$ precatalyst $(\mathrm{Zr}$ and $\mathrm{Cr}$ ). The polymer yields gradually increase with increasing catalyst loading. The low polymer yield obtained at a low catalyst loading indicates that impurities were present in the polymerization system which poisoned the catalysts. The polymer yields of the polymerization are plotted in Figure $3 \mathrm{a}$ as a function of catalyst loading. An approximately linear increase in polymer yield is observed. The linear fitted lines are based on the average polymer yields and the shown slopes indicate that the activity is $126.4 \mathrm{~kg} \mathrm{PE} / \mathrm{mmol} \mathrm{Zr} \cdot \mathrm{h}$ for $\mathrm{Zr}$ and $89.9 \mathrm{~kg} \mathrm{PE} / \mathrm{mmol} \mathrm{Cr} \cdot \mathrm{h}$ for $\mathrm{Cr}$, respectively. In Figure $3 \mathrm{~b}$, the catalyst loading is plotted as a function of polymer yield. The fitted lines indicate that poisoned catalyst amount is $0.0030 \mu \mathrm{mol}$ for $\mathrm{Zr}$ and $0.0064 \mu \mathrm{mol}$ for $\mathrm{Cr}$, respectively. The results clearly reveal that the poison limit for $\mathrm{Zr}$ and $\mathrm{Cr}$ in current polymerization is around $0.0045 \mu \mathrm{mol}$. The polymer yield is linear with increasing $\mathrm{Zr}$ and $\mathrm{Cr}$ loading implying that the $\mathrm{Al} / \mathrm{M}$ ratios were not impacting the polymer yields within the studied range.

In the DS system, control over the $\mathrm{Zr} / \mathrm{Cr}$ ratio was achieved via altering the mass ratios of the individually supported $\mathrm{Zr}$ and $\mathrm{Cr}$ catalysts. For the SS system, eight different batches of catalyst were synthesized with varied $\mathrm{Zr} / \mathrm{Cr}$ ratio from $9 / 1$ to $2 / 8$. The overall catalyst loading $(\mathrm{Zr}$ and $\mathrm{Cr}$ ) was maintained at $0.1 \mu \mathrm{mol}$. The polymerization results of DS and SS support system are shown in Tables 3 and 4, respectively. The individually supported $\mathrm{Zr}$ and $\mathrm{Cr}$ catalysts produced monomodal PEs which are presented in Table 3 ( $\mathrm{P}-\mathrm{Zr}$ and $\mathrm{P}-\mathrm{Cr}$ ) as a reference.

The molecular weight and molecular weight distribution of the polymers were characterized by HT-SEC. The data are summarized in Tables 3 and 4. It is shown that the molecular weight of $\mathrm{Cr}$ produced monomodal $(\mathrm{P}-\mathrm{Cr}$ ) is $3.5 \times 10^{6} \mathrm{~kg} \mathrm{~mol}^{-1}$, which is $\approx 10$ times higher than $\mathrm{Zr}$ produced monomodal ( $\mathrm{P}-\mathrm{Zr})$. The molecular weight

Table 1. Polymerization results of different Zr loadings.

\begin{tabular}{lcccccc}
\hline Entry ${ }^{\text {a) }}$ & Zr [ $[\mu \mathrm{mol}]$ & Al/Zr & \multicolumn{3}{c}{ Polymer yield [g] } & \multicolumn{2}{c}{$\begin{array}{c}\text { Average yield } \\
\text { [g] }\end{array}$} \\
\cline { 3 - 6 } & & Run 1 & Run 2 & Run 3 & - \\
2 & 0.01 & 3250 & Trace & Trace & Trace & 1.9 \\
3 & 0.02 & 1625 & 1.5 & 2.4 & 1.7 & 4.8 \\
4 & 0.04 & 813 & 5.0 & 4.3 & 5.2 & 7.7 \\
5 & 0.06 & 542 & 6.9 & 8.6 & 7.5 & 9.6 \\
6 & 0.08 & 406 & 9.5 & 9.4 & 9.9 & 12.1
\end{tabular}

a) Conditions: $\mathrm{MAO} / \mathrm{NS}=5 \mathrm{mg}$, ethylene pressure $=10 \mathrm{bar}$, temperature $=50^{\circ} \mathrm{C}$, time $=1 \mathrm{~h}$, cocatalyst $=0.5 \mathrm{mmol} i \mathrm{Bu} \mathrm{Al}_{3}$, solvent $=\mathrm{MCH}$ $100 \mathrm{~mL}$. 
Table 2. Polymerization results of different $\mathrm{Cr}$ loadings.

\begin{tabular}{|c|c|c|c|c|c|c|}
\hline \multirow[t]{2}{*}{ Entry ${ }^{a)}$} & \multirow{2}{*}{$\begin{array}{c}\mathrm{Cr} \\
{[\mu \mathrm{mol}]}\end{array}$} & \multirow[t]{2}{*}{$\mathrm{Al} / \mathrm{Cr}$} & \multicolumn{3}{|c|}{ Polymer yield [g] } & \multirow{2}{*}{$\begin{array}{c}\text { Average yield } \\
{[\mathrm{g}]}\end{array}$} \\
\hline & & & Run 1 & Run 2 & Run 3 & \\
\hline 1 & 0.01 & 3250 & Trace & Trace & Trace & - \\
\hline 2 & 0.02 & 1625 & 1.1 & 0.9 & 1.2 & 1.1 \\
\hline 3 & 0.04 & 813 & 3.1 & 3.4 & 2.9 & 3.1 \\
\hline 4 & 0.06 & 542 & 4.9 & 5.3 & 5.1 & 5.1 \\
\hline 5 & 0.08 & 406 & 6.8 & 6.9 & 7.1 & 6.9 \\
\hline 6 & 0.10 & 325 & 8.2 & 8.4 & 7.8 & 8.2 \\
\hline
\end{tabular}

a) Conditions: $\mathrm{MAO} / \mathrm{NS}=5 \mathrm{mg}$, ethylene pressure $=10$ bar, temperature $=50{ }^{\circ} \mathrm{C}$, time $=1 \mathrm{~h}$, cocatalyst $=0.5 \mathrm{mmol} i \mathrm{Bu} \mathrm{Al}^{\mathrm{Al}}$, solvent $=\mathrm{MCH}$ $100 \mathrm{~mL}$.

distributions (MWD $=\bar{M}_{\mathrm{w}} / \bar{M}_{\mathrm{n}}$ ) for both of the monomodal samples are around 2.5, which is typical for molecular catalysts immobilized on silica.

The HT-SEC may not accurately describe the wt\% of HMW phase due to a number of experimental parameters such as sample preparation (incomplete dissolution, degradation) and hardware limitations (column cut-off, etc.). Therefore, a set of physically blended bimodal PEs were prepared with varied ratios of two monomodal PEs. The MW and MWDs of the physically blended bimodal PEs were measured by HT-SEC, and a correlation was established by comparing the input and output values of the contents of HMW (Table S1 and Figure S3, Supporting Information). Thus, the HT-SEC results of DS and SS samples were further "calibrated" by the correlation from physically blended bimodal PEs, and the calibrated HMW phase are shown in Tables 3 and 4 as well.

The HT-SEC data in Tables 3 and 4 show a clear tendency in which the molecular weight and molecular distribution gradually increases with increasing $\mathrm{Cr}$ loading for both the DS and SS system. The HT-SEC curves of the DS and SS system produced bimodal PEs are plotted in Figure $4 a, b$, respectively. There is no significant shift in the individual peak maxima in HT-SEC curves indicating that the molecular weight capability of $\mathrm{Zr}$ or $\mathrm{Cr}$ catalysts are not significantly influenced by each other in both the DS and SS system. As shown in the plots, the height of the high molecular weight HT-SEC peak gradually increases with an increasing amount of the $\mathrm{Cr}$ catalyst. The results illustrate that the MW and MWDs of the bimodal PEs can be tuned via tuning the $\mathrm{Zr} / \mathrm{Cr}$ ratios in the combined catalysts systems.

In the individual catalyst polymerization reactions, the activities of $\mathrm{Zr}$ and $\mathrm{Cr}$ were calculated (126.4 kg PE/ mmol $\mathrm{Zr} \cdot \mathrm{h}$ and $89.9 \mathrm{~kg} \mathrm{PE} / \mathrm{mmol} \mathrm{Cr} \cdot \mathrm{h}$ ). The theoretical polymer yields and composition of the combined $\mathrm{Zr}$ and $\mathrm{Cr}$ catalysts systems can therefore be calculated based on the amount of $\mathrm{Zr}$ and $\mathrm{Cr}$ feed to the system to give a predicted Mw and split for the DS and SS system. The predicted polymer yields and experimental polymer yields of DS and SS system are plotted in Figure 5. It is shown that the DS and SS systems have relatively low polymer yields in comparison to the predicted polymer yields.

In order to investigate the behavior of the individual complexes in the bimodal polymerizations with SS and DS, the LMW phase $(\mathrm{Zr})$ and HMW phases $(\mathrm{Cr})$ in bimodal
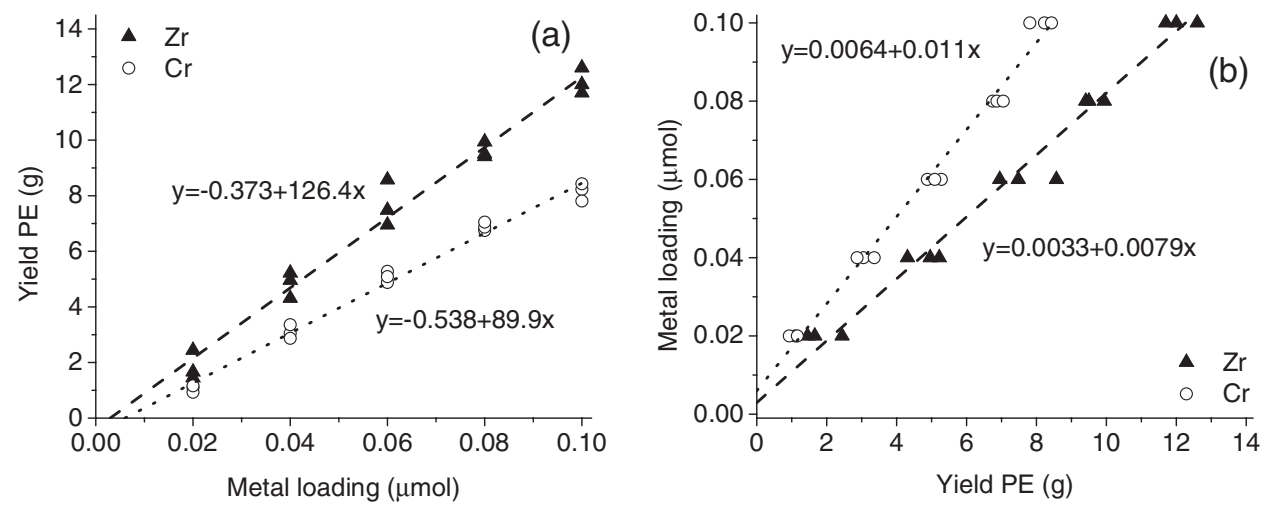

Figure 3. Polymer yield as a function of precatalyst loading for $\mathrm{Zr}$ and $\mathrm{Cr}$. 
www.mcp-journal.de

Table 3. Polymerization results of DS system.

\begin{tabular}{|c|c|c|c|c|c|c|c|c|c|}
\hline Sample & $\mathrm{Zr} / \mathrm{Cr}$ & $\begin{array}{l}\text { Yield } \\
\text { [g] }\end{array}$ & $\begin{array}{c}\bar{M}_{\mathrm{w}} \\
{\left[\mathrm{kg} \mathrm{mol}^{-1}\right]}\end{array}$ & $\begin{array}{c}\bar{M}_{\mathrm{n}} \\
{\left[\mathrm{kg} \mathrm{mol}^{-1}\right]}\end{array}$ & $\bar{M}_{\mathrm{w}} / \bar{M}_{\mathrm{n}}$ & $\begin{array}{l}\text { LMW }^{\mathrm{b})} \\
\text { [wt\%] }\end{array}$ & $\begin{array}{c}\text { HMW }^{b)} \\
\text { [wt\%] }\end{array}$ & $\begin{array}{l}\text { LMWc) } \\
\text { [wt\%] }\end{array}$ & $\begin{array}{c}\text { HMW }^{c)} \\
\text { [wt\%] }\end{array}$ \\
\hline $\mathrm{P}-\mathrm{Zr}$ & $1 / 0$ & 12.1 & 314 & 124 & 2.5 & 100 & 0 & 100 & 0 \\
\hline $\mathrm{P}-\mathrm{Cr}$ & $0 / 1$ & 8.2 & 3400 & 1330 & 2.6 & 0 & 100 & 0 & 100 \\
\hline DS1 & $9 / 1$ & 11.0 & 319 & 85 & 3.7 & 99.8 & 0.2 & 99.8 & 0.2 \\
\hline DS2 & $8 / 2$ & 9.9 & 494 & 125 & 4.0 & 94.2 & 5.8 & 93.6 & 6.4 \\
\hline DS3 & $7 / 3$ & 9.3 & 675 & 137 & 5.0 & 88.3 & 11.7 & 86.7 & 13.3 \\
\hline DS4 & $6 / 4$ & 8.7 & 858 & 145 & 5.9 & 82.4 & 17.6 & 79.8 & 20.2 \\
\hline DS5 & $5 / 5$ & 8.2 & 1170 & 178 & 6.6 & 72.4 & 27.6 & 68.1 & 31.9 \\
\hline DS6 & $4 / 6$ & 8.0 & 1250 & 185 & 6.7 & 69.8 & 30.2 & 65.0 & 35.0 \\
\hline DS7 & $3 / 6$ & 7.7 & 1630 & 248 & 6.6 & 57.5 & 42.5 & 50.6 & 49.4 \\
\hline DS8 & $2 / 8$ & 7.1 & 1950 & 287 & 6.8 & 47.1 & 52.9 & 38.4 & 61.6 \\
\hline
\end{tabular}

a) Conditions: $\mathrm{MAO} / \mathrm{NS}=5 \mathrm{mg}$, precatalyst loading $=0.1 \mu \mathrm{mol}$, ethylene pressure $=10 \mathrm{bar}$, temperature $=50{ }^{\circ} \mathrm{C}$, time $=1 \mathrm{~h}$, cocatalyst $=$ $0.5 \mathrm{mmol} \mathrm{Buu}_{3} \mathrm{Al}$, solvent $=\mathrm{MCH} 100 \mathrm{~mL} ;{ }^{\mathrm{b}}$ Calculated based on Equation (1); ${ }^{\mathrm{c}}$ Calibrated results.

PEs were investigated. Due to the fact that the immobilized catalysts have partially lost their single-site feature and the "calibration" for the HMW fraction, it is difficult to use the simple Schulz-Flory equation to deconvolute the HT-SEC curves. ${ }^{[50,51]}$ Therefore, the contents of HMW phase are calculated via the equation ${ }^{[45]}$

$$
f=\frac{M \mathrm{w}-M \mathrm{w}_{\mathrm{Zr}}}{M \mathrm{w}_{\mathrm{Cr}}-M \mathrm{w}_{\mathrm{Zr}}}
$$

where $M_{\mathrm{w}}$ is the weight-average molecular weight of bimodal PE from HT-SEC, $M w_{C r}$ is the weight average molecular weight of $\mathrm{P}-\mathrm{Cr}, \mathrm{Mw}_{\mathrm{Zr}}$ is the weight average molecular weight of $\mathrm{P}-\mathrm{Zr}$ and $f$ is HMW phase content of DS and SS produced bimodal PEs. The calculated results are shown in Tables 3 and 4.

The yields of the $\mathrm{Zr}$ and $\mathrm{Cr}$ (based on calibrated results) of the bimodal polymerization systems are plotted in
Figure 6. The calculated LMW and HMW contents (solid line) are obtained based on the predicted activities of individual polymerizations with the $\mathrm{Zr}$ and $\mathrm{Cr}$ (Figure 3a). Figure $6 \mathrm{a}$ is the comparison of LMW contents in the DS and SS system. It is observed that the LMW fractions produced in DS and SS system are approximately identical to the predicted values. These results illustrate that the activity of $\mathrm{Zr}$ in DS and SS system is not unduly influenced by the presence of the $\mathrm{Cr}$ complex. In the SS system, less HMW phase is recovered than the predicted values which are shown in Figure $6 \mathrm{~b}$. This indicates that either $\mathrm{Cr}$ was partly deactivated in the presence of the $\mathrm{Zr}$ complex or that the polymerization environment at the local active site was different for $\mathrm{Cr}$ in the presence of $\mathrm{Zr}$ and thus the overall polymer yields decreased in the SS system.

For the DS system, the catalysts were separately supported on different silica nanoparticles. This support

Table 4. Polymerization results of SS system.

\begin{tabular}{|c|c|c|c|c|c|c|c|c|c|}
\hline Sample & $\mathrm{Zr} / \mathrm{Cr}$ & $\begin{array}{l}\text { Yield } \\
{[\mathrm{g}]}\end{array}$ & $\begin{array}{c}\bar{M}_{\mathrm{w}} \\
{\left[\mathrm{kg} \mathrm{\textrm {mol } ^ { - 1 }}\right]}\end{array}$ & $\begin{array}{c}\bar{M}_{\mathrm{n}} \\
{\left[\mathrm{kg} \mathrm{mol}^{-1}\right]}\end{array}$ & $\bar{M}_{\mathrm{w}} / \bar{M}_{\mathrm{n}}$ & $\begin{array}{c}\text { LMW }^{\text {b) }} \\
\text { [wt\%] }\end{array}$ & $\begin{array}{c}\left.\text { HMW }^{b}\right) \\
\text { [wt\%] }\end{array}$ & $\begin{array}{l}\text { LMWc) } \\
\text { [wt\%] }\end{array}$ & $\begin{array}{c}\text { HMW }^{c} \\
\text { [wt\%] }\end{array}$ \\
\hline SS1 & $9 / 1$ & 9.7 & 408 & 136 & 3.0 & 97.0 & 3.0 & 96.9 & 3.1 \\
\hline SS2 & $8 / 2$ & 9.1 & 538 & 157 & 3.4 & 92.7 & 7.3 & 91.9 & 8.1 \\
\hline SS3 & $7 / 3$ & 8.4 & 625 & 151 & 4.1 & 89.9 & 10.1 & 88.6 & 11.4 \\
\hline SS4 & $6 / 4$ & 7.8 & 724 & 168 & 4.3 & 86.7 & 13.3 & 84.8 & 15.2 \\
\hline SS5 & $5 / 5$ & 7.3 & 855 & 170 & 5.0 & 82.5 & 17.5 & 79.9 & 20.1 \\
\hline SS6 & $4 / 6$ & 7.1 & 1080 & 173 & 6.2 & 75.3 & 24.7 & 71.5 & 28.5 \\
\hline SS7 & $3 / 6$ & 5.8 & 1470 & 221 & 6.7 & 62.7 & 37.3 & 56.7 & 43.3 \\
\hline SS8 & $2 / 8$ & 5.2 & 1760 & 253 & 7.0 & 53.1 & 46.9 & 55.4 & 54.6 \\
\hline
\end{tabular}

a) Conditions: $\mathrm{MAO} / \mathrm{NS}=5 \mathrm{mg}$, precatalyst loading $=0.1 \mu \mathrm{mol}$, ethylene pressure $=10$ bar, temperature $=50{ }^{\circ} \mathrm{C}$, time $=1 \mathrm{~h}$, cocatalyst $=0.5 \mathrm{mmol} i \mathrm{Bu}_{3} \mathrm{Al}$, solvent $=\mathrm{MCH} 100 \mathrm{~mL} ;{ }^{\mathrm{b})}$ Calculated based on Equation (1); ${ }^{\mathrm{c}}$ Calibrated results. 

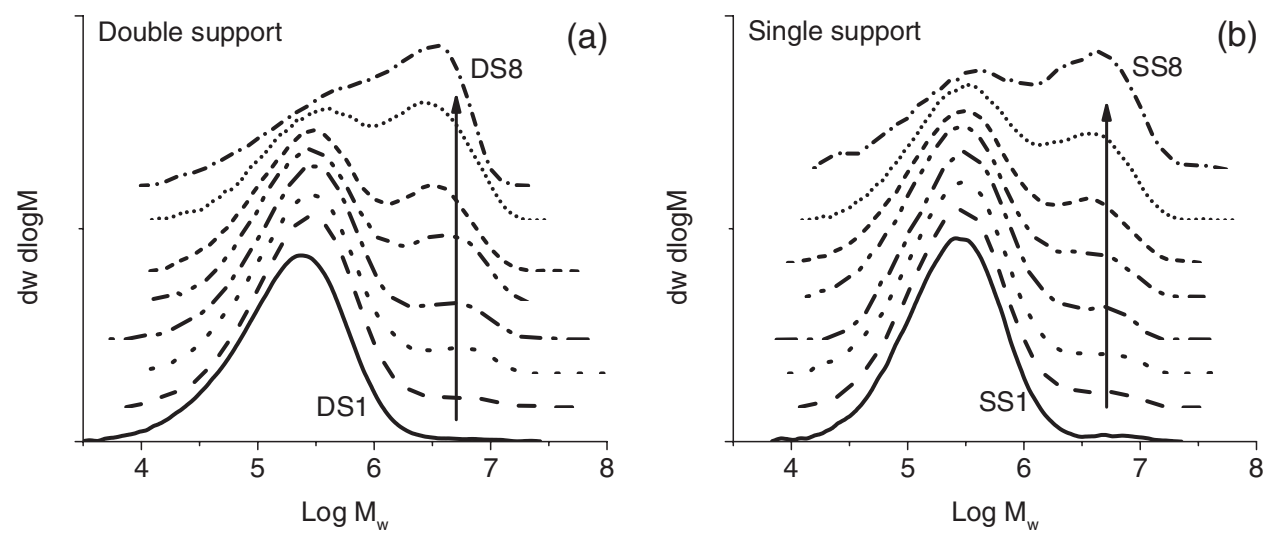

Figure 4. HT-SEC traces of bimodal PE samples obtained by the a) DS and b) SS system.

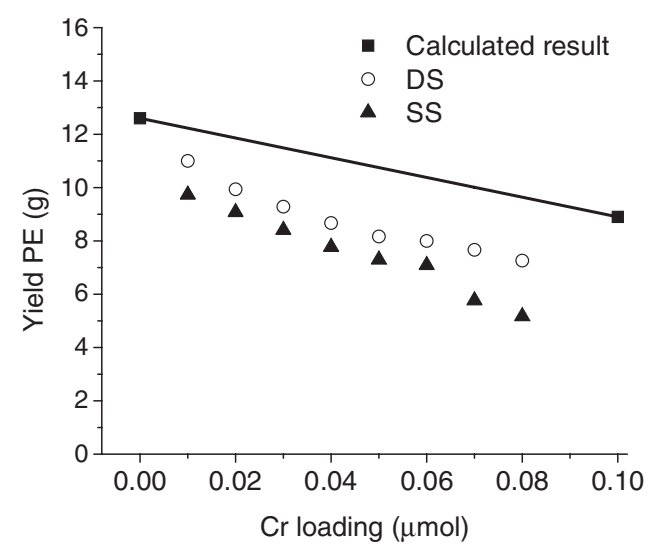

Figure 5. The polymer yields of DS and SS systems compared with the calculated polymer yield.

strategy was expected to prevent the interaction between the $\mathrm{Zr}$ and $\mathrm{Cr}$ catalysts. However, the possible "communication" between the $\mathrm{Zr}$ and $\mathrm{Cr}$ catalyst seems still to exist when comparing the values of HMW phase with the predicted yields (Figure 6b).

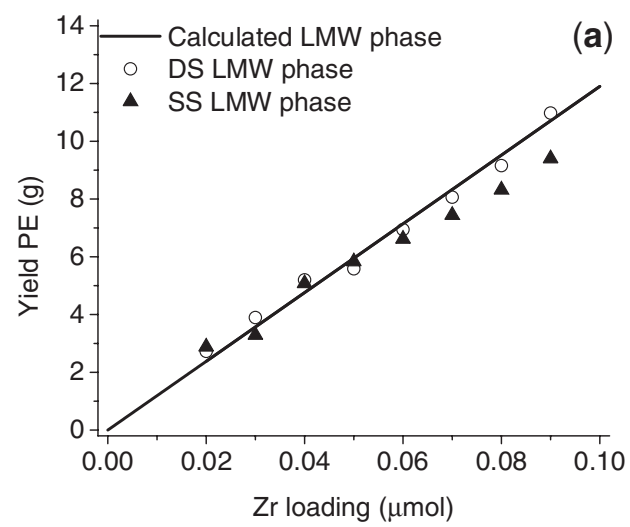

To elucidate the influences of the environment on the catalytic performance of the catalysts, a few polymerization reactions were conducted using the SS system at different temperatures and pressures. The HT-SEC curves of the obtained PEs are shown in Figure 7. It is shown that the performances of the precatalysts are strongly influenced by the temperature and the pressure. Due to the very high activity of the nanosilica supported catalysts, the rate of monomer diffusion from gas to solution might be lower than the rate of polymerization. Therefore, the monomer concentration at a local active site might be lower than the expected value for a $\mathrm{Cr}$ complex in bimodal systems. In DS system, the low monomer concentration result in less HMW PE being produced. This feature is more evident in the SS system because precatalysts are intimately supported on the silica particles and thus a lower polymer yield of HMW PE is observed (Figure 6b). Final the kinetic profiles of the individual component may be affected, unfortunately we had no facility to study this.

Besides the effect of the local polymerization environment, cocatalyst-induced catalyst leaching might also

Figure 6. Catalyst independent performance in DS and SS system: a) yields of Zr produced LMW phase and b) yields of $\mathrm{Cr}$ produced HMW phase.

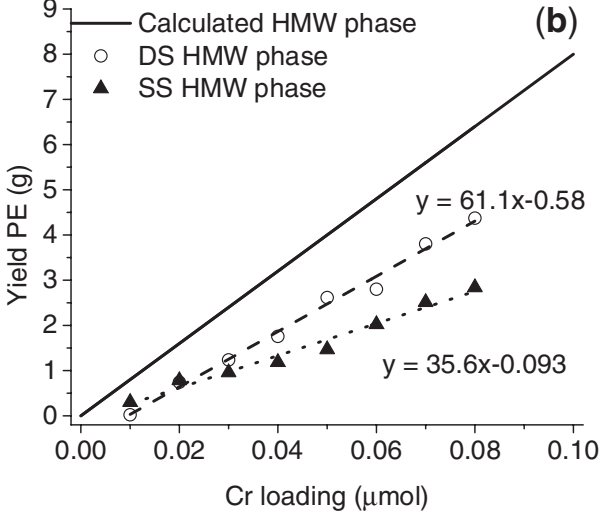



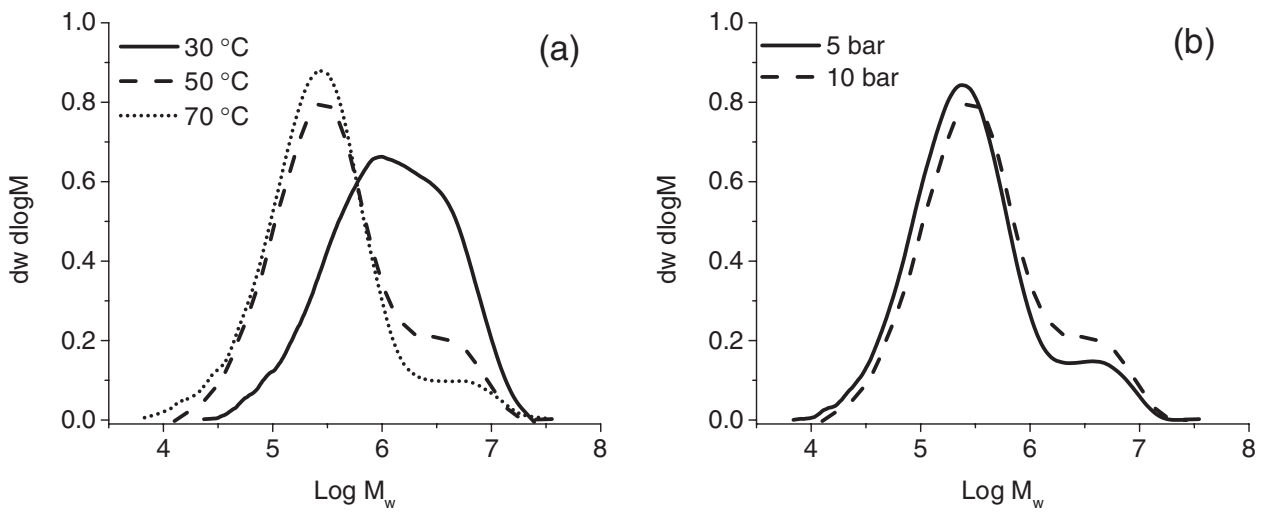

Figure 7. Catalyst system: single support $\mathrm{Zr} / \mathrm{Cr}=50 \% / 50 \%$. a) HT-SEC of PEs produced at 10 bar but at different temperatures. b) HT-SEC of the PEs produced at $50{ }^{\circ} \mathrm{C}$ but at different pressures. Conditions: $\mathrm{MAO} / \mathrm{NS}=5 \mathrm{mg}$, time $=1 \mathrm{~h}$, cocatalyst $=0.5 \mathrm{mmol} i \mathrm{Bu} \mathrm{Al}^{\mathrm{Al}}$, solvent $=\mathrm{MCH}$ $100 \mathrm{~mL}$.

affect in the catalytic performance of the catalysts. ${ }^{[52]}$ The leached catalyst can act as a homogeneous catalyst, which can result in reactor fouling during or after polymerization. Nevertheless, one of the features of a homogeneous catalyst is a rapid decay of activity. ${ }^{[53]}$

The produced polymer particles are probed by scanning electron micrograph (SEM). Agglomerates of polymer particles are observed with no evidence of reactor fouling (Figures S4 and S5, Supporting Information). However, due to the very small particle size and the agglomeration, it is rather difficult to observe the reactor fouling from SEM images. To elucidate if cocatalyst-induced catalysts leaching occurred in our polymerization systems, the individually supported $\mathrm{Zr}$ and $\mathrm{Cr}$ catalysts particles were treated with $0.5 \mathrm{mmol} i \mathrm{Bu}_{3} \mathrm{Al}$ prior to polymerization. Ethylene polymerizations were carried out using the filtrate of the reactants as catalysts. The results show that only the filtrate of the $\mathrm{Cr}$ catalyst particles exhibited some activity in ethylene polymerization (Figure S6, Supporting Information). This observation reveals that cocatalyst-induced $\mathrm{Cr}$ leaching indeed occurred during polymerization. One could imagine that such leaching is more likely to occur in the SS system because the later supported $\mathrm{Cr}$ complex has more chance to contact the cocatalyst. The activity of the leached $\mathrm{Cr}$ complex may decay rapidly and thus a low yield of HMW is obtained in the bimodal system.

\section{Conclusions}

Molecular precatalysts $\mathrm{Zr}$ and $\mathrm{Cr}$ were successfully immobilized on silica nanoparticles using DS and SS strategies. To approach a process which can tailor the MW and MWD, several parameters including temperature and cocatalyst/catalyst ratios were taken into account. Using the DS and SS catalyst systems, two sets of bimodal molecular weight distribution PEs were synthesized under identical polymerization conditions. The results showed that MW and MWD of bimodal PEs can be varied via tuning the ratios of the catalysts. However, the two catalyst systems were still not able to predictively tailor the MW and MWDs because of the detrimental reaction between the precatalysts. The detrimental reaction deactivates part of $\mathrm{Cr}$ complex in both catalyst systems. The reason may be due to the divergence of polymerization environment at the local active site, or the cocatalyst caused precatalyst leaching. The results presented in this paper demonstrated the multivariate nature of the systems which makes it an extremely challenging to approach a truly MW and MWDs tailored process even using the DS system.

\section{Supporting Information}

Supporting Information is available from the Wiley Online Library or from the author.

Acknowledgements: The authors thank Anne B. Spoelstra (Eindhoven University of Technology) for her help with TEM analysis. The authors wish to thank Fabian F. Karbach and Robbert Duchateau for constructive discussions. The authors acknowledge the financial support by the Eindhoven University of Technology (TU/e).

Received: October 11, 2016; Revised: November 8, 2016; Published online: January 3, 2017; DOI: 10.1002/macp.201600490

Keywords: bimodal distribution; polyethylene; silica nanoparticle; single-site catalyst

[1] P. Smith, P. J. Lemstra, H. C. Booy, J. Polym. Sci., Polym. Phys. Edn. 1981, 19, 877.

[2] M. K. Musib, Int. J. Biol. Eng. 2012, 1, 6. 
[3] P. S. M. Barbour, M. H. Stone, J. Fisher, Biomaterials 1999, 20, 2101.

[4] S. Rastogi, L. Kurelec, J. Cuijpers, D. Lippits, M. Wimmer, P. J. Lemstra, Macromol. Mater. Eng. 2003, 288, 964.

[5] R. H. Olley, I. L. Hosier, D. C. Bassett, N. G. Smith, Biomaterials 1999, 20, 2037.

[6] A. S. Maxwell, A. P. Unwin, I. M. Ward, M. I. Abo El Maaty, M. M. Shahin, R. H. Olley, D. C. Bassett, J. Mater. Sci. 1997, 32, 567.

[7] S. J. Oh, J. Lee, S. Park, Ind. Eng. Chem. Res. 2005, 44, 8.

[8] J. B. F. P. Alt, L. L. Böhm, H-F. Enderle, Macromol. Symp. 2001 , $163,135$.

[9] M. Stürzel, S. Mihan, R. Mülhaupt, Chem. Rev. 2016, 116, 1398.

[10] L. L. Böhm, Angew. Chem. Int. Ed. 2003, 42, 5010.

[11] J. R. Severn, in Tailor-Made Polymers: Via Immobilization of Alpha-Olefin Polymerization Catalysts (Eds: J. R. Severn, J. C. Chadwick), Wiley-VCH Verlag $\mathrm{GmbH} \&$ Co. $\mathrm{KGaA}$, Weinheim, Germany 2008, Ch. 4.

[12] J. D. Kim, J. B. P. Soares, G. L. Rempel, J. Polym. Sci., Part A: Polym. Chem. 1999, 37, 331.

[13] F. López-Linares, A. D. Barrios, H. Ortega, J. O. Matos, P. Joskowicz, G. Afrifoglio, J. Mol. Catal. A: Chem. 2000, 159, 269.

[14] N. Kukalyekar, L. Balzano, G. W. M. Peters, S. Rastogi, J. C. Chadwick, Macromol. React. Eng. 2009, 3, 448.

[15] A. Kurek, S. Mark, M. Enders, M. O. Kristen, R. Mülhaupt, Macromol. Rapid Commun. 2010, 31, 1359.

[16] M. Ruff, C. Paulik, Macromol. React. Eng. 2012, 6, 302.

[17] M. Sturzel, Y. Thomann, M. Enders, R. Mülhaupt, Macromolecules 2014, 47, 4979 .

[18] W. M. Vega, A. Munoz-Escalona, US Patent 6605 676, 2003.

[19] B. J. Savatsky, J. H. Oskam, M. W. Blood, M. B. Davis, D. H. Jackson, T. R. Lynn, D. P. Zilker, US Patent 8318 872, 2012.

[20] F. C. Rix, S-C. Kao, R. Kolb, D. Li, C. A. Garcia-Franco, US Patent 8835 577, 2014.

[21] R. Kolb, D. Li, F. C. Rix, C. A. Garcia-Franco, US Patent 8088 704, 2012.

[22] S-C. Kao, F. C. Rix, D. Li, C. J. Harlan, P. A. Khokhani, US Patent 843 914, 2013

[23] J. B. Wagner, G. R. Giesbrecht, S-C. Kao, S. P. Jaker, PCT Int. Appl. 2014/149360, 2014

[24] M. D. Jensen, M. P. McDaniel, J. L. Martin, E. A. Benham, R. Muninger, G. Jerdee, A. M. Sukhadia, O. Yang, M. G. Thorn, US Patent 7041 617, 2006.

[25] J. L. Martin, E. A. Benham, M. E. Kertok, M. D. Jensen, M.P. McDaniel, G. R. Hawley, O. Yang, M. G. Thorn, M. Sukhadia, US Patent 7199 073, 2007.

[26] K. C. Jayaratne, M. D. Jensen, O. Yang, US Patent 7226 886, 2007.

[27] J. L. Martin, M. G. Thorn, M. P. McDaniel, M. D. Jensen, O. Yang, P. J. DesLauriers, M. E. Kertok, US Patent 7312 283, 2007
[28] O. Yang, K. C. Jayaratne, M. D. Jensen, M. P. McDaniel, J. L. Martin, M. G. Thorn, J. T. Lanier, T. R. Crain, US Patent 8 $268944,2012$.

[29] O. Yang, M. P. McDaniel, T. R. Crain, A. P. Masino, T. H. Cymbaluk, J. D. Stewart, US Patent 8957 168, 2015

[30] Y. Satoh, Y. Harada, US Patent 2015/001849, 2015.

[31] B. Hideki, S. Yasuo, Y. Takashi, H. Yasuyuki, S. Yoshiho, T. Yasushi, S. Yusuke, S. Masao, T. Daisuke, US Patent 8785 574, 2014.

[32] Y. Ishihama, R. Asakawa, T. Sakuragi, T. Fukuda, K. Sakata, M. Aoki, K. Kawagishi, K. Yoshimoto, US Patent 2014/0194277, 2014.

[33] S. Mihan, R. Karer, H. Schmitz, D. Lilge, US Patent 8003 740, 2011.

[34] S. Mihan, V. Fraaije, H. Schmitz, US Patent 8859 451, 2014.

[35] F. Fantinel, G. Mannebach, S. Mihan, G. Meier, I. Vittorias, US Patent 8957 158, 2015.

[36] H. Vogt, S. Mihan, G. Mannebach, L. Richter-Lukesova, M. Meierhöfer, H. Brüning, PCT Int. Appl. 2015/055392, 2015.

[37] H. Schmitz, S. Mihan, US Patent 8435 911, 2013.

[38] R. M. Lopez, M. C. Martin, A. O. Prieto, R. J. Sancho, P. J. Campora, R. P. Pilar Palma, L. A. M. Naz, R. C. M. Perez, Eur. Patent 2003 166, 2008.

[39] N. Friederichs, G. Nourdin, X. Wei, in Tailor-Made Polymers: Via Immobilization of Alpha-Olefin Polymerization Catalysts (Eds: J. R. Severn, J. C. Chadwick), Wiley-VCH Verlag GmbH \& Co. KGaA, Weinheim, Germany 2008, Ch. 8.

[40] C. R. Landis, M. D. Christianson, Proc. Natl. Acad. Sci. USA 2006, 103, 15349 .

[41] N. Zhao, R. Cheng, X. He, Z. Liu, B. Liu, R. Zhang, Y. Gao, E. Zou, S. Wang, Macromol. Chem. Phys. 2014, 215, 1434.

[42] F. A. Kunrath, R. F. deSouza, O. L. Casagrande Jr., Macromol. Rapid Commun. 2000, 21, 277.

[43] R. Huang, C. E. Koning, J. C. Chadwick, Macromolecules 2007, 40, 3021.

[44] B. Paredes, R. van Grieken, A. Carrero, J. Moreno, A. Moral, Chem. Eng. J. 2012, 213.

[45] A. Kurek, S. Mark, M. Enders, M. Stürzel, R. Mülhaupt, J. Mol. Catal. A: Chem. 2014, 383-384, 53.

[46] S. Markus, A. Kurek, T. Hees, Y. Thomann, H. Blattmann, R. Mülhaupt, Polymer 2016, 102, 112.

[47] K.-J. Chu, J. B. P. Soares, A. Penlidis, J. Polym. Sci., Part A: Polym. Chem. 2000, 38, 462.

[48] J. R. Severn, J. C. Chadwick, Dalton Trans. 2013, 42, 8979.

[49] J. R. Severn, J. C. Chadwick, Macromol. Chem. Phys. 2004, 205, 1987.

[50] J. B. P. Soares, Macromol. Symp. 2007, 257, 1.

[51] J. B. P. Soares, A. E. Hamielec, Polymer 1995, 36, 2257.

[52] F. F. Karbach, J. R. Severn, R. Duchateau, ACS Catal. 2015, 5, 5068 .

[53] J. R. Severn, R. Duchateau, J. C. Chadwick, Polym. Int. 2005 $54,837$. 